\title{
Erratum to: The example of the IPCC does not vindicate the Value Free Ideal: a reply to Gregor Betz
}

\section{Stephen John}

Received: 13 August 2013 / Accepted: 7 July 2014 / Published online: 13 February 2015

(C) Springer Science+Business Media Dordrecht 2015

\section{Erratum to: Euro Jnl Phil Sci \\ DOI 10.1007/s13194-014-0095-4}

The author regrets that an Erratum to his article published in January 2015, Volume 5, Issue 1 , is required due to an oversight.

This article mistakenly mentions the 'International Panel on Climate Change' in the abstract, the keywords, the opening paragraph on page 1, and in the bibliography. This should be: 'Intergovernmental Panel on Climate Change'.

The online version of the original article can be found at http://dx.doi.org/10.1007/s13194-014-0095-4.

S. John $(\bowtie)$

Department of History and Philosophy of Science, University of Cambridge, Free School Lane,

Cambridge CB2 3RH UK, England

e-mail: sdj22@cam.ac.uk 